\title{
Cytological Studies on mosses from Papua New Guinea 1. Introduction and the family Orthotrichaceae.
}

\author{
H.P. Ramsay ${ }^{1}$, H. Streimann ${ }^{2} \&$ D.H. Vitt ${ }^{3}$ \\ ${ }^{1}$ School of Biological Sciences, Macquarie University, Sydney N.S.W. 2109 Australia. \\ ${ }^{2}$ Cryptogamic Herbarium, Centre for Plant Biological Diversity Research, Canberra, A.C.T. \\ 2601 Australia. \\ ${ }^{3}$ Department of Botany, University of Alberta, Edmonton, Alberta, T6G 2E9 Canada.
}

\begin{abstract}
Chromosome numbers with information on meiotic behaviour are recorded for the first time for the following taxa in the family Orthotrichaceae from Papua New Guinea - Desmotheca apiculata (Dozy \& Molk.) Lindb. ex Card.n=6; Macromitrium incurvifolium (Hook. \& Grev.) Schwaegr. n=9, M. longicaule C. Muell. n=6(5+X/y), M. orthostichum Nees ex Schwaegr. n=7 (6+X/y), M. salakanum C. Muell. $\mathrm{n}=9$, M. similirete Bartr. $\mathrm{n}=9$. M. streimannii $\mathrm{Vitt} \mathrm{n}=9(8+\mathrm{m}) ;$ Schlotheimia emarginato-pilosa Herz. $\mathrm{n}=9$ and $S$. macgregorii Broth. \& Geh. $\mathrm{n}=11$.
\end{abstract}

\section{Introduction}

The bryoflora of New Guinea is exceptionally rich, and of particular interest, as it contains a high proportion of endemics (Zanten \& Pócs 1981). The great variation in altitude (sea level to 4,000 metres) due to its geological history, together with the tropical climate have resulted in a wide variety of ecosystems with a rich and diverse bryoflora. Phytogeographically the eastern Malesian region, of which New Guinea is a part, forms a centre of species richness for many Southern Hemisphere moss families such as Dawsoniaceae, Hypnodendraceae and Spiridentaceae but also for tropical genera in cosmopolitan families such as Bryaceae, Orthotrichaceae, Sematophyllaceae and Pottiaceae.

The major vegetation types in New Guinea reflect floristic origins, for example the Eucalyptus woodlands (Australian element), lowland forests (Malesian element), montane forests (Gondwanan element) and tropical grassland (peregrine element) Mosses of the Australian element include 
Powellia and Racopilum (Zanten \& Pocs 1981) while Dawsonia and Hypnodendron are examples of Gondwanan elements with high species diversity in New Guinea (Ramsay et al. 1986).

Many mosses considered endemic to New Guinea are montane species suggesting that their evolution post-dated the upheaval of the central mountain ranges at the end of the Tertiary (Zanten $\&$ Pocs 1981). Schuster (1983) described montane and alpine areas as acting as 'biotic islands' subject to stress, genetic drift and rapid rates of evolution. In some cases migration to adjacent islands followed (e.g., Dawsonia). Intergrading polymorphic species occur frequently in a number of genera (e.g., Macromitrium, Garovaglia, Bryum, Hypnodendron) which suggests active speciation (Zanten \& Pocs 1981). In general the New Guinea bryoflora have relatively few affinities with that of Australasia, being primarily Malesian.

In a comparison between the alpine bryofloras of Australia, New Guinea and New Zealand, Ramsay et al. (1986) found that only twelve alpine species were common to Australia and New Guinea, while fourteen occurred in both New Zealand and New Guinea. We have no complete data yet on the overall species similarities for all mosses but about $53 \%$ of the alpine mosses in New Guinea appear to be endemic. Whether this endemism is real, or the result of taxonomic misunderstanding, will not be resolved until the bryoflora has been revised in detail. Recent and current taxonomic research by Koponen \& Norris with others in the last more than ten years on the Huon Peninsula, the Freida River and East and West Sepik in Papua New Guinea has already demonstrated the richness of the bryoflora and has led to the discovery of new taxa.

A revision of the Orthotrichaceae in the area by Vitt (1990) and Vittetal. (1993, 1995) has recently been completed. The family Orthotrichaceae is well represented from lowland forests to the subalpine. Within the Macromitrioideae Vitt(1990) and Vitt et al. (1993, 1995) recognise twenty-nine species of Macromitrium, five species of Schlotheimia and one species in both Macrocoma and Groutiella. Desmotheca with a single species (Vitt 1990) is a lowland taxon.
Of the twenty-nine species of Macromitrium, thirteen have been recorded only from New Guinea while sixteen are known from Western Melanesia. Only two of the species occurring in New Guinea (M. incurvifolium and M. microstomum) also occur in Australia while two (M. microstomum and $M$. angulatum) are in New Zealand.

\section{Cytological Studies on Mosses from New Guinea}

There are a few records of chromosome numbers for mosses from New Guinea: Dawsonia, two species (Ramsay 1967), and Hypnodendron, two species (Ramsay 1983, 1987) (Table 1). Some chromosome number data on the Orthotrichaceae in Papua New Guinea appeared in Ramsay \& Vitt (1984) without detailed information. These included the preliminary chromosome numbers of $\mathrm{n}=6,7,8,9$, for several unidentified Macromitrium species and the numbers $\mathrm{n}=6$ for Desmotheca $\mathrm{sp}$., $\mathrm{n}=9,11$ for Schlotheimia spp. (Table 1). The identity of the species and other information on these latter counts as well as chromosome data for additional taxa in the Orthotrichaceae are presented here.

Counts for approximately twenty moss genera in fifteen additional families from Papua New Guinea will appear elsewhere (Ramsay \& Streimann in prep.).

All collections examined in these studies were made by H. Streimann in Papua New Guinea (the eastern part of New Guinea) during 1982-3 whilst he was visiting lecturer at the Forestry College in Bulolo. Live specimens, sealed in plastic bags were sent by airmail (with quarantine approval) arriving within a week. On arrival, they were sprayed with distilled water to freshen them, and maintained at $18-20^{\circ} \mathrm{C}$ under fluorescent lights for some days before capsules were examined for meiosis. This ensured that any capsules examined had come into meiotic division after stabilisation. Some losses were inevitable, but a large proportion of capsules maturing after arrival exhibited normal meiosis. Abnormal ones were discarded.

Chromosome counts were obtained from at least $60 \%$ of species sent. A few taxa, particularly Hypnodendron and Rhodobryum survived and 


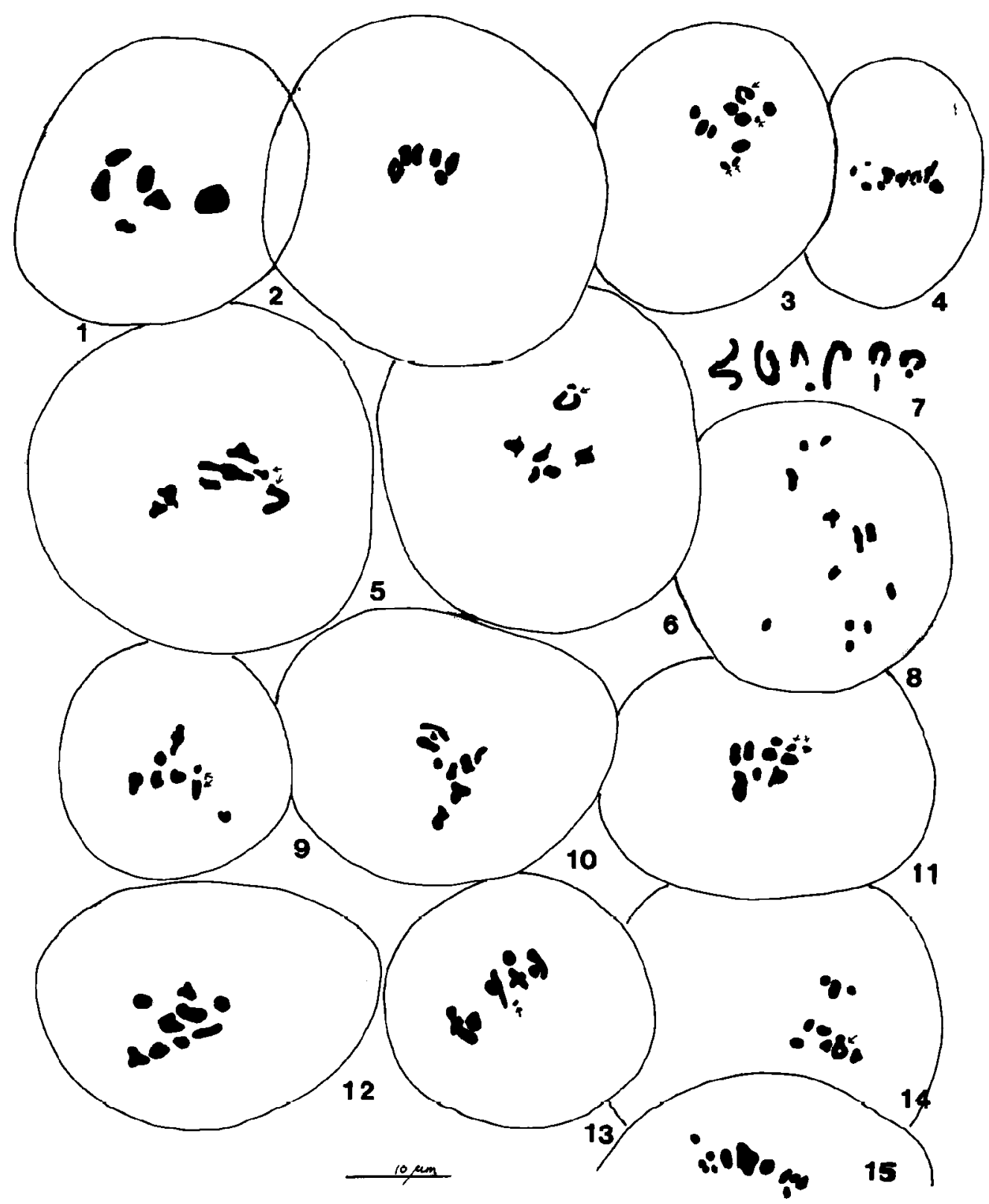

Figures 1-15. Meiosis in sporocytes. 1-2. Desmotheca apiculata $\mathrm{n}=6$ 1. early MI, note six large bivalents. 2. side view of MI. 3-4. Macromitrium incurvifolium $\mathrm{n}=9$. 3. MI, note dimorphic bivalent with the large and small chromosomes already disjoined (arrows) and another bivalent separating early (arrows) (27/82). 4. MI, (23b/82). 5-8. Macromitrium longicaule $\mathrm{n}=6.5$. . (67/82), MI, note rod-shaped bivalent showing the large and small chromosome disjoined (arrows). 6. MI, the dimorphic bivalent is ring-shaped with the small and large chromosome just separated (arrow). 7. various configurations of the dimorphic bivalent. 8. (75/82), MII, showing six chromosomes at each end. 9. Macromitrium orthostichum $\mathrm{n}=9$. 9. $(28 / 82)$, MI, note the two unequal chromosomes of the dimorphic bivalent have disjoined (arrows). 10-11. Macromitrium salakanum $\mathrm{n}=9$ 10. (31/82), MI. 11. MI, note small bivalent disjoining early (arrows). 12. Macromitrium similirete $\mathrm{n}=9,(6 / 82)$, MI. 13. Macromitrium streimanii $\mathrm{n}=$ $9(8+m)$, note m-bivalent at MI (arrow). 14. Schlotheimia emarginato-pilosa $\mathrm{n}=9$ (77/82), MI, note dimorphic bivalent present (arrow). 15. Schlotheimia macgregorii $\mathrm{n}=11$, MI, no dimorphic bivalent seen but one large bivalent is present. 
continued to grow well for weeks or months enabling mitotic counts. The period during which specimens were sent covered the end of the tropical monsoon wet and all the dry season (May 1982February 1983) but the period most suitable for meiotic studies was June-November (between the wet and dry seasons) corresponding to the months when the various stages of the life history, meiosis and sporophyte production were most active. All Chromosome Vouchers will be deposited at NSW with duplicates at CANB.

Orthotrichaceae

Much chromosome data are now available for the family Orthotrichaceae with information for species from genera in North America, Europe including the United Kingdom, Australia and New Zealand (summarised under separate genera in Fritsch 1991, Ramsay 1993).

Desmotheca Lindb.

Various opinions have been expressed concerning the relationships of the genus Desmotheca within the Orthotrichaceae. Although Vitt (1990) agrees with Crum (1987) that Desmotheca is 'patristically distinct from the assemblage of species around Macromitrium,' Vitt believes that 'cladistic rationale indicates that the genus is best kept in the Section Macromitrioideae' with genera such as Macromitrium, Schlotheimia, Groutiella and Macrocoma rather than creating a separate subfamily as suggested by Crum (1987). The genus is distinguished from Macromitrium and other Orthotrichaceae by the strikingly dimorphic sterile and fertile branches, complete absence of peristome, almost sessile capsules, the enlarged, sheathing, lingulate perichaetial leaves and the delicate, small, mitrate, hairy calyptrae covering only the operculum. Like many species of Macromitrium the primary stems are creeping, spores are anisomorphic and it is pseudautoicous (phyllodioicous) with dwarf males (Vitt 1990).

Desmotheca apiculata (Dozy \& Molk.) Lindb. ex Card. Ramsay 60/82 n=6 Fig. 1-2.

Desmotheca apiculata is the only one of the two species in the genus Desmotheca (Vitt 1990) known to occur in New Guinea where it is found between
50-900 m. Desmotheca apiculata is distributed in New Caledonia and New Guinea, the Philippines, India, Burma, Thailand and Vietnam(Vitt 1990: Fig. 3).

The chromosome number $\mathrm{n}=6$ was first recorded for an undetermined species of Desmotheca in Ramsay \& Vitt (1984) without detail. The number is confirmed here as $\mathrm{n}=6$ and the species is $D$. apiculata (Fig. 1-2, Table 2, Appendix 1). Although the species is anisosporous with dwarf males, no dimorphic bivalent was observed. The chromosome complement resembled that of $\mathrm{Or}$ thotrichum species with $\mathrm{n}=6$ chromosomes (see Ramsay \& Lewinsky 1984, Ramsay 1993).

\section{Macromitrium Brid.}

Ramsay \& Vitt $(1984,1986)$ included, without detail, the chromosome numbers $n=6,7$, in addition to $n=8,9$ previously recorded for Australasian species, for several undetermined species of Macromitrium from Papua New Guinea. Chromosome data are presented here for six species of Macromitrium in New Guinea.

Macromitrium incurvifolium (Hook. \& Grev.) Schwaegr. Ramsay 23a/82, 23b/82, 27/82 n=9 Fig. 3-4.

Macromitrium incurvifolium is a widespread lowelevation species known from Hawaii and Pitcairn Island, and distributed from New Guinea west to Java and south to northeastern Queensland, near Cairns, Australia(Vitt\& Ramsay 1985). It is related to $M$. leratii Broth. \& Par. from Australia and New Caledonia, M. peraristatum Broth., a Lord Howe Island endemic, $M$. helmsii Paris and M. gracile (Hook.) Schwaegr. from New Zealand, and $M$. fuscescens Schwaegr., a widespread South Pacific species.

Macromitrium incurvifolium is distinctly anisosporous and pseudautoicous with dwarf males. Branches are short with only a few bearing perichaetia.

There are no previous chromosome number records for $M$. incurvifolium. Chromosome numbers for related Australasian species include $n=9$ for $M$. gracile, and $\mathrm{n}=8$ for $M$. leratii. both of 
Table 1. Previous reports of Chromosome Numbers for New Guinean Orthotrichaceae

Taxon

Polytrichaceae (Dawsoniaceae)

Dawsonia beccarii Broth. \& Geh. Dawsonia crispifolia Dix. $\mathrm{n}=7$ $\mathrm{n}=7$

$\mathrm{n}=4,2 \mathrm{n}=8$

Hypnodendraceae

Hypnodendron dendroides (Brid.) Touw $\mathrm{n}=5,2 \mathrm{n}=10 \quad$ Ramsay 1987

Publication

Ramsay 1967 (In Löve) Ramsay 1967 (In Löve)

Orthotrichaceae (the following chromosome numbers recorded without species identification).

Macromitrium spp.

Desmotheca sp.

Schlotheimia spp. $\mathrm{n}=6,7,8,9$

$\mathrm{n}=6$

$n=10,11$

\author{
Ramsay \& Vitt 1984 \\ Ramsay \& Vitt 1984 \\ Ramsay \& Vitt 1984
}

which have a dimorphic bivalent (Ramsay \& Vitt 1986).

Two populations from three separate collections were examined (Table 2, Appendix 1) from Papua New Guinea. The chromosome number was determined as $n=9$ (Fig. 3-4). A dimorphic bivalent (Fig. 3) was present. The members of the dimorphic bivalent were often separated by metaphase I (Fig. 3-4) and sometimes the smaller member separated into chromatids early.

Macromitrium longicaule C. Muell. Ramsay 65/ 82, 75/82, 26/82, 67/82 n=6 (5+X/y) Fig. 5-8.

Macromitrium longicaule which includes M. brachystele Dix. and M. papuanum Dix., is closely related to $M$. noguchianum Schultze-Motel and M. sublongicaule C. Muell. It occurs at midelevations between 1400-2500 m, and is known from Java as well as New Guinea.

Macromitrium longicaule is anisosporous and pseudautoicous. Based on the regularity with which capsules are produced from perichaetia, the species can be considered reproductively very successful. On one branch examined, six perichaetia and six mature capsules, one from each perichaetium, were produced from a total of 78 archegoniaformed. Seven dwarf males were located on the branch mainly in leaf axils, although two were located at the base of one perichaetium.

The undetermined New Guinean species with $n=6$ chromosomes (Ramsay \& Vitt 1984, 1986) has been identified as $M$. longicaule. Four separate populations (Table 2, Appendix 1) were examined to confirm the chromosome number as $n=6(5+\mathrm{X} /$ y) with a distinct dimorphic bivalent (Fig. 5-6), the number being confirmed at Metaphase II (fig. 8). Ramsay \& Vitt (1986) also illustrated the meiotic complement and several configurations of the dimorphic bivalent (Fig. 77, p.30). Additional illustrations are given here (Fig. 5-6) showing the dimorphic bivalent appearing as circular to rodshaped (Fig. 7), sometimes with the two dissimilar chromosomes forming an elongate configuration at prometaphase due to chiasma forming in only one arm (Fig. 5). The dimorphic bivalent behaved in a fashion similar to those described for some 
Table 2. New chromosome numbers in Papua New Guinean Orthotrichaceae

[Ramsay voucher number given here, see Appendix 1. for collection details.] $\mathrm{P}=$ pseudautoicous with dwarf males, $\mathrm{A}=$ anisomorphic spores]

Voucher Species

$\mathrm{n}=$

sex spores

Desmotheca

60/82 Desmotheca apiculata

6

$\mathrm{P}$

A

Macromitrium

23a/82 M. incurvifolium

9

P A

23b/82 M. incurvifolium

9

P A

7/82 M. incurvifolium

9

P A

67/82 M. longicaule

$6(5+\mathrm{X} / \mathrm{y}) \quad \mathrm{P}$

A

65/82 M. longicaule

$6(5+\mathrm{X} / \mathrm{y}) \quad \mathrm{P} \quad \mathrm{A}$

75/82 M. longicaule

$6(5+\mathrm{X} / \mathrm{y}) \quad \mathrm{P} \quad \mathrm{A}$

26/82 M. longicaule

$6(5+\mathrm{X} / \mathrm{y}) \quad \mathrm{P} \quad \mathrm{A}$

28/82 M. orthostichum

$7(6+X / y) \quad P \quad A$

31/82 M. salakanum

9

P A

6/82 M. similirete

9

P A

68/82 M. streimannii

$9(8+m)$

P A

Schlotheimia

77/82 S. emarginato-pilosa

9

P A

25/82 S. macgregorii

11

P A 
Australasian Macromitrium species (Ramsay 1966, Ramsay \& Vitt 1986) and for the American Schlotheimia lancifolia Bartr. and S. rugifolia (Hook) Schwaegr. described by Anderson (1980).

Macromitrium orthostichum Nees ex Schwaegr. Ramsay 28/82 n=7 (6+X/y) Fig. 9.

Macromitrium orthostichum, together with $M$. angulatum Mitt. and M. erubescens Bartr., form a distinctive group of species. Macromitrium orthostichum is known from Java and Sumatra eastward to New Guinea and the Philippines. In New Guinea, it occurs at lower and mid-elevations between $650-2600 \mathrm{~m}$. The species is distinguished readily by the leaves arranged in neat rows. It is pseudautoicous with dwarf males and the spores are anisomorphic.

This is the first report of a chromosome number for M. orthostichum or for any species in this group. Ramsay \& Vitt (1986) provided a drawing of the complement and the appearance of the dimorphic bivalent (Fig. 78, p.30). There are seven bivalents at metaphase I of meiosis (Fig. 9) in the single population studied here (Table 2, Appendix 1), one of which was a dimorphic bivalent. The count was confirmed at anaphase II with seven chromosomes present at each of the four poles (too small to illustrate).

Macromitrium salakanum C. Muell. Ramsay $31 /$ $82 \mathrm{n}=9$ Fig. $10-11$.

Macromitrium salakanum is closely related to $M$. angustifolium Mitt. and M. acuminatum (Reinw. \& Hornsch.) C. Muell. All three species are widespread in Melanesia, being distributed at lower elevations. Spores are anisomorphic and dwarf males have been illustrated for the species by Ernst-Schwarzenbach(1943).

There are no previous chromosome number reports for M. salakanum. In our studies the chromosome number was determined as $n=9$ (Fig. 1011) from a single population (Table 2, Appendix 1). No clearly dimorphic bivalent was noted but one other bivalent sometimes disjoined early at metaphase I (Fig. 11).
Macromitrium similirete Bartr. Ramsay $6 / 82 \mathrm{n}=9$

Fig. 12.

Macromitrium similirete is endemic to New Guinea where it has been collected from mid-elevations between 880-2700 m. Its relationships are with $M$. incurvifolium, $M$. parvifolium Dix. and $M$. streimannii. The spores are anisomorphic and dwarf males are stalked with a single perigonium containing the antheridia.

There are no previous chromosome counts for $M$. similirete. In the single population examined in these studies (Table 2, Appendix 1) the chromosome number was determined as $n=9$ (Fig. 12). However, the single capsule examined here, in which some divisions were observed, had mainly second divisions and the number is tentative at this stage.

Macromitrium streimannii Vitt Ramsay 68/82n= 9(8+m)Fig. 13

This is a new species of Macromitrium endemic to New Guinea (Vitt et al. 1995) occurring between $800-1750 \mathrm{~m}$. It is related to $M$. similirete and is similarly anisosporous and pseudautoicous with dwarf males.

The chromosome number was determined as $n=9$ $(8+m)$ and included an m-bivalent (Fig. 13) in the single population examined (Table 2, Appendix 1). This is the species reported as having $n=8$ chromosomes in Ramsay \& Vitt (1984) but on closer examination the m-bivalent was noted adding to the number.

\section{Schlotheimia}

There are reports of chromosome numbers for the genus Schlotheimia from Australia, Japan and the United States of America (Fritsch 1991). In Australia, S. brownii Schwaegr. has n=11 $(10+\mathrm{m})$ chromosomes (Ramsay 1979), in Japan S. japonica Besch. \& Card. has $\mathrm{n}=10$ and in U.S.A. both $S$. lancifolia and $S$. rugifolia have the number $n=8$ (7 $+\mathrm{X} / \mathrm{Y})$, the $\mathrm{X} / \mathrm{Y}$ representing a dimorphic bivalent (Anderson 1980). This variation in chromosome numbers in Schlotheimia parallels that in the related genus Macromitrium as does the presence 
of dimorphic bivalents in some species.

There are five species of Schlotheimia in Papua New Guinea (Vitt et al. 1993), none of which occur in Australasia. Ramsay \& Vitt (1984) mentioned chromosome numbers for two undetermined species in New Guinea as n=10,11. Here we provide the species names and correct the report of $n=10$ to $n=9$.

Schlotheimia emarginato-pilosa Herz. Ramsay $77 / 82 \mathrm{n}=9(8+X / y)$ Fig. 14

Schlotheimia emarginato-pilosa, endemic to New Guinea, has been collected from both closed and more open habitats between 1,700-2,000 m. It grows on tree trunks, on Pandanus and on logs and fallen branches (Vittet al. 1993). It differs from all Australasian species in the prorate basal cells and from the widespread Old World S. grevilleana Mitt. in possessing 8-ribbed capsules.

This is the first chromosome number report for $S$. emarginato-pilosa (Table 2, Appendix 1). The complement of $n=9(8+X / y)$ included a dimorphic bivalent (Fig. 14). The dimorphic bivalent is similar to that recorded for American species (Anderson 1980).

Schlotheimia emarginato-pilosa is a pseudautoicous (phyllodioicous) species with anisomorphic spores (Table 2).

Schlotheimia macgregorii Broth. \& Geh. Ramsay 25/82 n=11 Fig. 15.

Schlotheimia macgregorii grows at altitudes of 1,500-3,500 $\mathrm{m}$ in both primeval mountain forests and in more open sites such as tree fern savannas. It is epiphytic on tree trunks, tree ferns, Pandanus, Coprosma or on tree branches, fallen branches and rarely on soil after the branches have rotted. The species is endemic to Western Melanesia.

The count of $\mathrm{n}=11$ is the first chromosome number report for S. macgregorii (Table 2, Appendix 1). The eleven bivalents included one large, but apparently uniform, bivalent (Fig. 15). No dimorphic bivalent was detected although the species is pseudautoicous (phyllodiocous) and has anisomorphic spores (Table 2). Further counts would be useful to check this.

\section{Discussion}

Macromitrium and Schlotheimia are interesting genera cytologically, both for the range of chromosome numbers present and the presence of a dimorphic bivalent at metaphase I of meiosis in some species that are sexually dimorphic (pseudautoicous) and anisosporous. The presence of such a bivalent at meiosis in many of the species with dwarf males suggests that this bivalent may be sex associated or that the sex may be chromosomally determined in these taxa (Ramsay 1966, 1979, Ramsay \& Vitt 1986).

In the Macromitrium species examined here all are pseudautoicous and anisosporous. The discovery of a six-chromosome species in Macromitrium provides a chromosome number link through to other members of the family such as Orthotrichum, suggesting that it is the base number. A dimorphic bivalent was noted in those species with $n=6 \& 7$ chromosomes, and in some 9-chromosome species. This corresponds to the situation in many of the Australasian taxa (Ramsay \& Vitt 1986). No dimorphic bivalent was detected in Desmotheca, but was present in one of the two Schlotheimia species examined, S. emarginato-pilos $a$ with $n=9$ chromosomes.

\section{Acknowledgments}

We wish to acknowledge the assistance given to $\mathrm{H}$. Streimann by the Principal of the Papua New Guinea Forestry College, Siage Kalogo, and students for field studies whilst in Papua New Guinea. We are grateful to the School of Biological Sciences, Macquarie University for providing H. Ramsay with facilities to carry out the chromosome studies whilst on leave from the University of New South Wales in 1984.

\section{References}

Anderson, L.E. 1980. Cytology and reproductive biology of mosses. In R.J. Taylor \& A.E. Leviton (eds). The Mosses of North America. AAS Pacific Division, San Francisco. 
Crum, H.A. 1987. Leratia and its place in the Orthotrichaceae, subfamily Macromitrioideae.Memoirs of the New York Botanical Garden 45:602-606.

Ernst-Schwarzenbach, M. 1943. The sexual dimorphism of tropical mosses of the genus Macromitrium. Farlowia 1: 195-198.

Fritsch, R. 1991. Index to bryophyte chromosome counts. Bryophytorum Bibliotheca 40:1-352.

Ramsay H.P. 1966. Sex chromosomes in Macromitrium. Bryologist 69: 293-311.

Ramsay H.P. 1967. In A. Love IOPB Chromosome number reports XIV. Taxon 16:552-571.

Ramsay, H.P. 1979. Anisospory and sexual dimorphism in the Musci. In G.C.S. Clarke \& J.G. Duckett (eds). Bryophyte Systematics. Systematic Association Special Volume 14:281-316. Academic Press, London.

Ramsay, H.P. 1983. A moss with four chromosomes. Lindbergia 9: 89-92.

Ramsay, H.P. 1987. Cytological and other studies on the Hypnodendraceae. Memoirs of the New York Botanical Garden 45:135-153.

Ramsay, H.P. 1993. Chromosome studies on some Australasian Orthotrichaceae II. Ulota and Zygodon with additional studies on Orthotrichum, Schlotheimia and Macromitrium. Journal of the Hattori Botanical Laboratory 74:183-192.

Ramsay, H.P. \& J. Lewinsky. 1984. Chromosome numbers on some Australasian Orthotrichaceae (Musci) I. Orthotrichum. New Zealand Journal of Botany 22:345-351.

Ramsay, H.P., H. Streimann, A.V. Ratkowsky, R.D. Seppelt \& A. Fife 1986. Australasian alpine bryophytes. In Barlow, B. (ed.), Flora and Fauna of Alpine Australasia: Ages and Origins. pp. 301- 335. CSIRO, Melbourne.

Ramsay, H.P. \& D.H. Vitt 1984. Distribution, cytotaxonomy and sexuality of Macromitrium in the Pacific. Journal of the Hattori Botanical Laboratory 55:23-33.

Ramsay, H.P. \& D.H. Vitt 1986. The Macromitrium complex in Australasia (Orthotrichaceae: Bryopsida) Part III. Cytotaxonomy. Journal of the Hattori Botanical Laboratory 61:1-43.

Schuster, R.M. 1983. Phytogeography of Bryophyta. In R.M. Schuster New Manual of Bryology. Vol. 1, chapter 10:463-626. Hattori Botanical Laboratory, Nichinan.

Vitt, D.H. 1972. Genera of the Orthotrichaceae. Beihefte zur Nova Hedwigia 71:261-268.

Vitt, D.H. 1990. Desmotheca (Orthotrichaceae): Gondwanan fragmentation and the origin of a Southeast Asian genus. Tropical Bryology 3:7988

Vitt, D.H., T. Koponen \& D.H. Norris. 1993.Bryophyte flora of the Huon Peninsula, Papua New Guinea LIII. Ulota and Schlotheimia (Orthotrichaceae, Musci). Acta Botanica Fennica 148:5-25.

Vitt, D.H., T. Koponen \& D.H. Norris. 1995.Bryophyte Flora of the Huon Peninsula, Papua New Guinea. LIV. Macrocoma, Macromitrium, Groutiella, Desmotheca (Orthotrichaceae, Musci). Acta Botanica Fennica 150 (in press).

Vitt, D.H. \& H.P. Ramsay. 1985. The Macromitrium complex in Australasia (Bryopsida: Orthotrichaceae) Part I. Taxonomy and phylogenetic relationships. Journal of the Hattori Botanical Laboratory 59:325-451.

Zanten, R.O. van \& T. Pocs. 1981. Distribution and dispersal of bryophytes. In W. Schultze-Motel (ed.), Advances in Bryology 1:480-562. Cramer, Vaduz.

Appendix 1. Collection details for Ramsay chromosome number vouchers. Duplicate specimen vouchers are held at CANB while the actual chromosome vouchers will be lodged at NSW.

Desmotheca

60/82 D. apiculata, Forestry College, Bulolo, 27 September 1982 H. Streimann 24829.

Macromitrium

23a,b/82 M. incurvifolium, Forestry College, Bulolo, 26 July $1982 H$. Streimann 22517A.

27/82 M. incurvifolium, Forestry College, Bulolo, 26 July 1982 H. Streimann $22517 B$

67/82 M. longicaule, Nawata Banda, Bulolo, 3 October 1982 H. Streimann 24874.

65/82 M. longicaule, Watut River, 7 October 1982 H. Streimann 24948. 
75/82 M. longicaule, Upper Watut Valley, 14 October 1982 H. Streimann $85218 B$.

26/82 M. longicaule, Wau-Salamau track, 2 August 1982 H. Streimann 22567.

28/82 M. orthostichum, Wau-Salamau track, 2 August 1982 H. Streimann 22579.

31/82 M. salakanum, Watut River, 14 October $1982 \mathrm{H}$. Streimann 23083.

6/82 M. similirete, Hekwangi Village, Menyanngo, 2 May 1982 H. Streimann 19446.

68/82 M. streimannii, Upper Watut Valley, 14 October 1982 H. Streimann 25218A.

Schlotheimia

77/82 S. emarginato-pilosa, Gumi Divide near Bulolo, 13 October 1982 H. Streimann 25050.

25/82 S. macgregorii, Ekuti Divide, on Bulolo-Esuki Road, 3 August 1982 H. Streimann 22597. 